\title{
QUATERNARY GEOLOGY OF NORTHERN ALBERTA: IMPLICATIONS FOR KIMBERLITE EXPLORATION
}

\author{
M.M. Fenton, J.G. Pawlowicz, R.C. Paulen, G.J. Prior and R.A. Olson \\ Alberta Geological Survey, Alberta Energy and Utilities Board, Edmonton, Alberta, Canada
}

\section{INTRODUCTION}

During the last decade, a considerable amount of research has taken place in northern Alberta. Particular attention has been paid to the unique geological setting of northern Alberta's Quaternary history and the challenges of drift prospecting for diamonds here, relative to known methodologies that are well established within the Canadian Shield. Currently, 47 ultramafic diatremes have been discovered in three separate areas within the Western Canada Sedimentary Basin of northern Alberta: 2 non-kimberlitic pipes at Mountain Lake, 37 kimberlite pipes in the Buffalo Head Hills area and 8 kimberlite pipes in the Birch Mountains area. The kimberlite fields of northern Alberta differ from other Canadian kimberlite fields (e.g. Lac de Gras) in various ways from the perspective of drift prospecting in glaciated terrain. Such factors include the bedrock geology, glacial history, physiography and drift thickness.

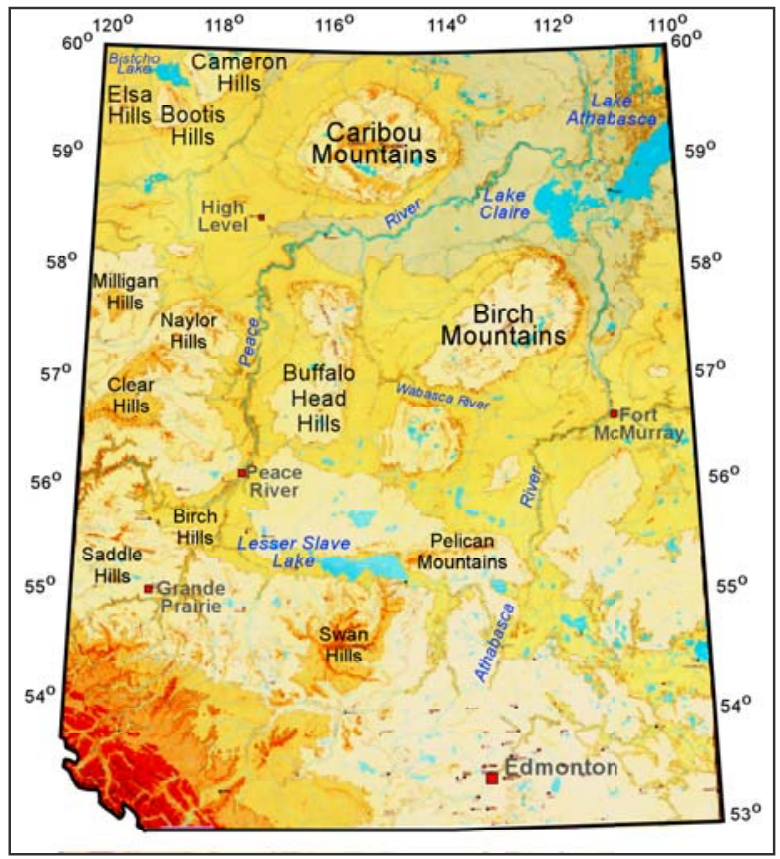

Figure 1. Relief and physiography of northern Alberta

Quaternary deposits are the surface materials and form the local landforms over virtually all of northern Alberta. Bedrock, which controls the broad elements of the physiography, rarely crops out. Most of the surficial deposits that occur were deposited during the Pleistocene glaciations. For the most part, the surficial materials and present-day landforms are a result of the last glacial event during the Late Wisconsin (25-12 ka $\mathrm{BP})$.

The physiography of northern Alberta (Figure 1) consists of a number of highlands: the Swan Hills, Pelican Mountains, Saddle Hills, Clear Hills, Naylor Hills, Milligan Hills, Buffalo Head Hills, Birch Mountains, Caribou Mountains, Cameron Hills, Bootis Hills and Elsa Hills. Separating these highlands are major drainage ways such as the Peace, Wabasca and Athabasca rivers (Pettapiece, 1986).

\section{BEDROCK GEOLOGY}

The Mountain Lake pipes occur within the Upper Cretaceous Wapiti Formation, which is composed mainly of non-marine sandstone. The kimberlites of the Buffalo Head Hills and Birch Mountain fields are hosted by a Cretaceous succession composed dominantly of marine shales of the Shaftesbury Formation and Smoky Group, which are separated by deltaic to marine sandstones of the Dunvegan Formation (Hamilton et al., 1999). This differs considerably from other prospective regions in Canada where exploration focuses on the Archean craton (e.g. Slave Province). There, exploration targets usually lie beneath small round lakes; this is generally a product of differential erosional as kimberlitic bedrock is considerably softer than rocks of the Canadian Shield that surround them. In Alberta, however, several of the kimberlites form topographic and/or bedrock highs due to their greater resistance to weathering and glacial erosion relative to the enclosing soft Cretaceous sedimentary rocks.

\section{BEDROCK TOPOGRAPHY}

The bedrock topography (Figure 2) is the result of erosion during the Tertiary and probably at least the early Quaternary (Fenton et al. 1994). The bedrock topography generally resembles the surface 
topography/physiography to some degree, with the high and lows in the bedrock surface being reflected in the surface topography. Two basic topographic elements are evident: the broad generally northward and eastward trending valleys, and intervening uplands formed by eroded bedrock remnants. Note however, that in the vicinity of the Cameron, Bootis and Elsa Hills in northwestern Alberta, the bedrock elevation is considerably lower and than the surface expression of these hills, hence the high topography reflects an accumulation of thick surficial deposits.

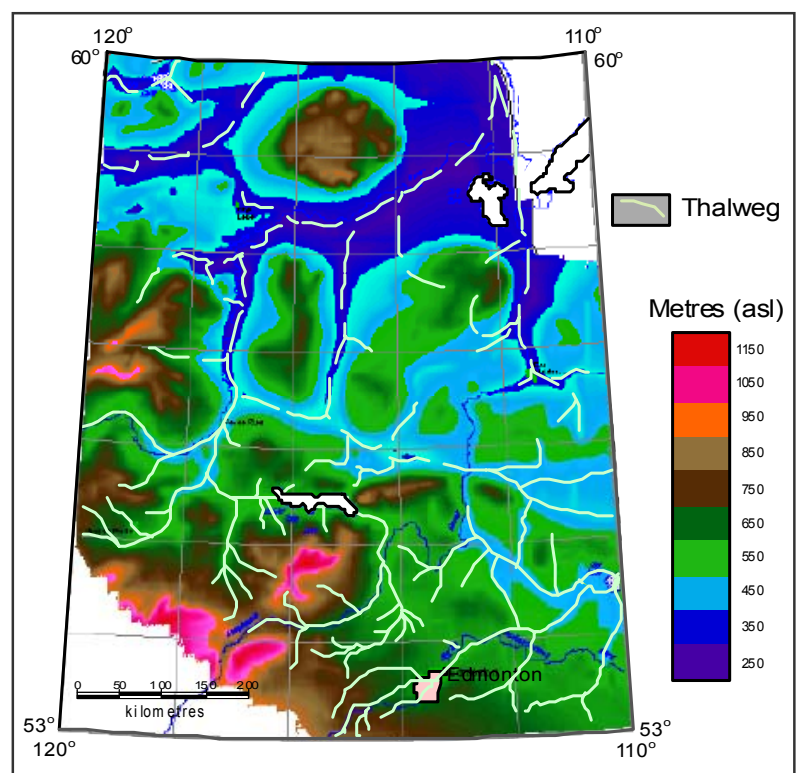

Figure 2. Bedrock topography of northern Alberta (modified from Pawlowicz and Fenton, 1995a)

The bedrock topographic lows in northern Alberta are primarily the major preglacial valleys. Most of these valleys were likely eroded prior to the first glacial advance to reach the region. However, the existence of preglacial sediment at the base of these valleys is needed to confirm this assumption. Preglacial sediment in northern Alberta consists of coarse sediment, predominantly quartzite clasts, derived from the Cordillera.

\section{DRIFT THICKNESS}

The thickness of unconsolidated sediment overlying the bedrock, including sediment of both Late Tertiary and Quaternary age, is shown in Figure 3. The Tertiary sediment is confined largely to the lower portions of the preglacial channels. The drift thickness varies from $0 \mathrm{~m}$ in a few areas to $300 \mathrm{~m}$ in the Wiau channel which extends westward from the Saskatchewan boarder, north of latitude $55^{\circ} \mathrm{N}$. The drift is generally thick in these channels, but in places it can also thicken on the uplands. The preglacial channels, for the most part, have been partially filled, thus lowering the local relief on the present land surface.

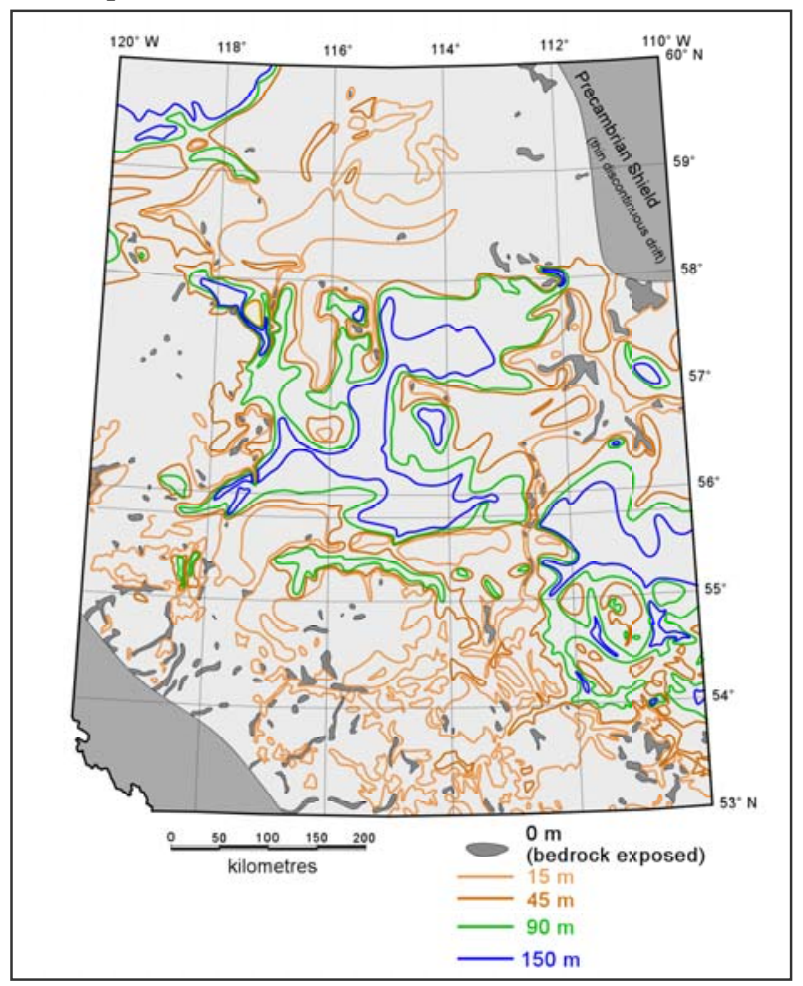

Figure 3. Drift thickness of northern Alberta (modified from Pawlowicz and Fenton, 1995b)

Deposition within these channels was more or less continuous from the close of the Tertiary into the Quaternary. The deposition of nonglacial fluvial sediment continued until the onset of glaciation. The ice sheets advanced into Alberta up-drainage, essentially blocking the preglacial drainage. The first stratigraphic marker positively identifying Quaternary sediment, at any particular site, is the stratigraphically lowest appearance of till, or other glacial stratified sediment, that contains exotic material transported westward and/or southward by the advancing Laurentide glaciers. Typically, this exotic material is from the Precambrian Shield and/or the adjacent Paleozoic carbonate outcrop belt.

Factors influencing the location of thick accumulations of sediment in northern Alberta are: (1) the preglacial valleys, (2) bedrock highlands and remnants, (3) areas of ice marginal still-stands and (4) bedrock contacts or scarps (Fenton et al, 1994). The preglacial valleys influenced deposition in a number of ways: (1) they acted as sediment traps, accumulating thick sequences of stratified sediment as the advancing or retreating 
glaciers dammed the eastward flowing streams; (2) they influenced glacial dynamics and contributed to the accumulation and preservation of comparatively thick sequences of till within them; (3) during the nonglacial intervals, they formed lows favorable to initial erosion and channel formation, and this led to subsequent infilling of these channels by nonglacial stratified sediment; and (4) because of their low position in the landscape, they tended to preserve the existing sediment from erosion during subsequent glacial advances (Fenton and Pawlowicz, 2000).

The effect of deposition at an ice marginal stillstand can be seen at the Cameron, Bootis and Elsa Hills regions in northwestern Alberta. The limited subsurface data indicates these uplands are composed primarily of a thick sequence of Quaternary sediment deposited during one or more intervals when the ice margin was stationary in the region long enough to deposit a substantial amount of sediment. Bedrock uplands may also include areas of thick drift accumulation. These areas may be the result of a thick, comparatively widespread, accumulation of glaciogenic sediment (till, and glaciofluvial and/or glaciolacustrine sediment) or the infilling of comparatively narrow preglacial or interglacial channels.

Bedrock contacts, buried channel margins and scarps are all areas where ice sheets have deformed the bedrock and drift to deposit comparatively thick accumulations of thrusted bedrock and glacial sediment. Minor glaciotectonic features have been recognized in many areas of northern Alberta and more are being discovered as the surficial mapping program moves into new areas (cf. Paulen 2002). Areas of known deformation include portions of the Birch Mountains, Pelican Mountain, northeastern flank of the Caribou Mountains, south of Rock Island Lake, at Fawcett Lake and Muskwa Lake, and in the Fort McMurray region. One example of glaciotectonism and transport is the Cooking Lake Erratic, a discontinuous mass of the Grand Rapids Sandstone that is exposed areally over a number of hectares east of Edmonton. It was thrusted into the Laurentide Ice Sheet and transported more or less intact about $300 \mathrm{~km}$ from its subcrops south of Fort McMurray. A detailed discussion of glacial tectonism can be found in Fenton and Pawlowicz (2000).

\section{SEDIMENT AND STRATIGRAPHY}

Glacial deposits in northern Alberta generally comprise till, glaciolacustrine and glaciofluvial sediments. The nature of these deposits reflects broad aspects of the bedrock lithologies and patterns of glacial and glaciofluvial transport. The soft poorly consolidated Mesozoic bedrock, together with the well developed relief, allowed the glaciers to incorporate considerable quantities of debris both as finely divided sediment and large masses incorporated through glaciotectonism. Clay and silt till is mainly derived from the fine-grained Cretaceous bedrock, with sand components from Cretaceous and Tertiary sandstones. Minor yet important components of the till come from bedrock of the Precambrian Shield, Paleozoic carbonates at the margin of the shield, and quartzites and other clastic rocks from the Cordillera.

The subsequent melting released this sediment to form a variety of landforms including streamlined terrain, hummocky stagnant ice terrain (Figure 4), deformation terrain, palimpsest terrain and low relief terrain, each of which contains different proportions of basal debris. The tills are generally much finer texture than those deposited on the Shield, which tend to be of a silty sand composition (Scott 1976; Vincent 1989). The till texture ranges from clayey silt to silty clay with less than 2 percent clasts of pebble size or larger. The exception in Northern Alberta is the sandy tills north of Fort McMurray and east of the Athabasca River.

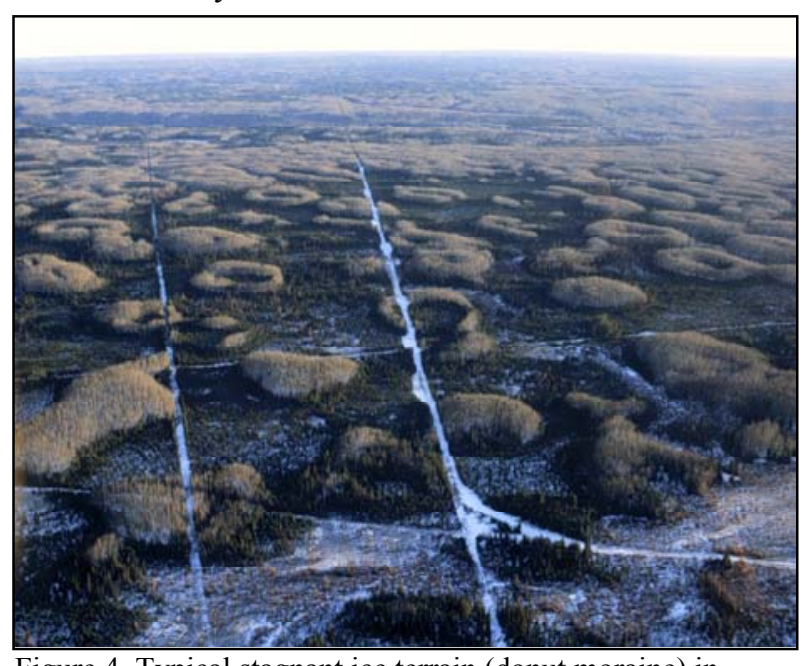

Figure 4. Typical stagnant ice terrain (donut moraine) in northern Alberta (photo by R. Paulen).

Multiple glacial advances were documented in the Cold Lake region, with five tills recognized (Andriashek and Fenton 1989). Three lithologically distinct till sheets were recognized in the Cooking Lake moraine immediately east of Edmonton, with the upper till overlying organic remains dated to middle Wisconsin age (Andriashek and Fenton 1997). Their work also correlated these till sheets with those in the Cold Lake 
region. Recently, multiple tills have been identified in the Buffalo Head Hills kimberlite field. An older, oxidized till sheet was identified in boreholes and to the southwest in a deep burrow pit. Preliminary results from overburden drilling show that this older till (premiddle Wisconsin) may have a higher concentration of kimberlite indicator minerals than the younger till (late Wisconsin) that overlies it. This may provide some insight on the difficulty of mapping kimberlite dispersal trains from samples collected at or near surface.

\section{ICE FLOW HISTORY}

Glacial advances in northern Alberta originated from the Laurentide Ice Sheet. The Laurentide Ice Sheet generally flowed across Alberta in a southwesterly direction (Dyke et al. 2002). The difficulty in piecing together the ice flow history in Alberta is the scarcity of erosional ice flow indicators, such as striations, roche moutonnées and sculpted bedrock forms. The soft Cretaceous bedrock was prone to intense erosion, glacial deformation and ice-thrusting. Distribution of erratics, streamlined landforms, and pebble fabrics can provide clues on regional ice movement (Fulton 1995;
Klassen 1989). A preliminary ice flow history is presented in Figure 5.

\section{DRIFT PROSPECTING}

Indicator mineral surveys of near-surface till have been completed by the Alberta Geological Survey to document dispersal from kimberlites of the Buffalo Head Hills field (Dufresne et al. 1996; Fenton and Pawlowicz 1997; Pawlowicz et al. 1998; Eccles et al. 2001; Prior et al. 2003). In the southwestern Buffalo Head Hills an indicator mineral dispersal train, characterized by elevated counts of pyrope and chromite grains, is up to $6 \mathrm{~km}$ wide and extends for over $15 \mathrm{~km}$ (Prior et al. 2003). Overburden thickness in this area generally varies from about $2 \mathrm{~m}$ to $>25 \mathrm{~m}$. Therefore, despite the relative complexity of northern Alberta's Quaternary geology, drift prospecting is a viable exploration method in areas of thin to moderate overburden. However, as a consequence of the Quaternary history, indicator mineral dispersal trains from kimberlite sources may be palimpsest in nature.

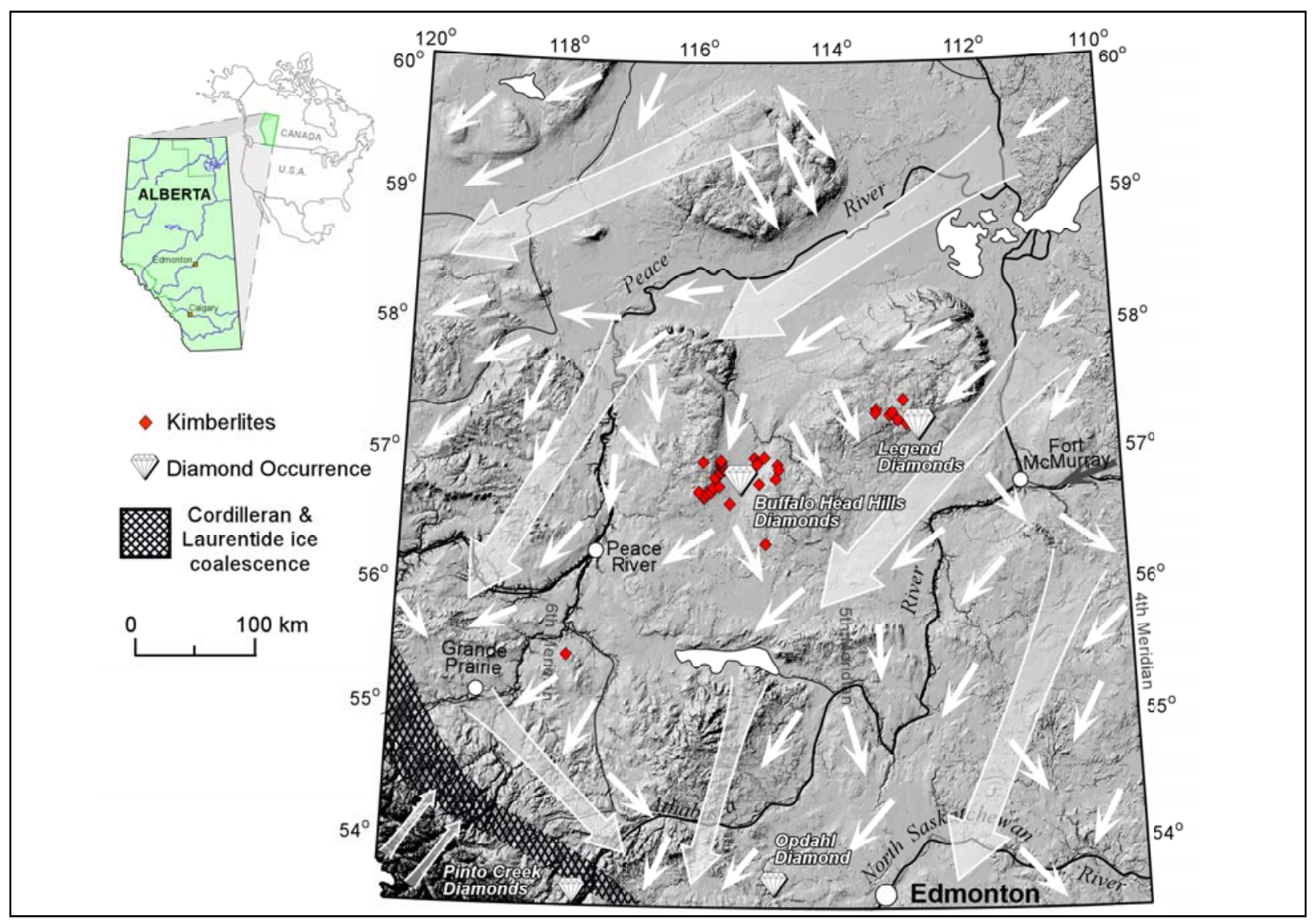

Figure 5. Ice flow of the Laurentide Ice Sheet during the Late Wisconsin. The large arrows indicate ice flow at glacial maximum (derived from Fulton 1989 and Prest et al. 1968). The smaller arrows indicate general flow directions of latest Late Wisconsin ice (Klassen 1989; Paulen et al. 2002) 


\section{REFERENCES}

Andriashek, L.D. and Fenton, M.M., 1989. Quaternary stratigraphy and surficial geology of the Sand River area 73L. Alberta Research Council Bulletin 57, 154 p.

Andriashek, L.D. and Fenton, M.M., 1997. Evidence of Pre Late-Wisconsinan Glaciation in the Edmonton area, Central Alberta. Canadian Society of Petroleum Geology and Society of Economic Paleontologists and Mineralogists, Joint Convention, June 1997, Calgary, Alberta, Program with Abstracts, p. 24.

Dufresne, M. B., Eccles, D. R., McKinstry, D. R., Schmitt, D. R., Fenton, M. M., Pawlowicz, J. G. and Edwards, W. A. D., 1996. The diamond potential of Alberta. Alberta Energy and Utilities Board, Alberta Geological Survey, Bulletin No. 63, 158 p.

Dyke, A.S., Andrews, J.T., Clark, P.U., England, J.H., Miller, G.H., Shaw, J. and Veillette, J.J. 2002. The Laurentide and Innuitian ice sheets during the Last Glacial Maximum. Quaternary Science Reviews, 21: 9-31.

Eccles, D.R., Haynes, M. and Csanyi, W., 2001. Diamond and metallic-mineral potential of the Peerless Lake map area, north-central Alberta. Alberta Energy and Utilities Board, Alberta Geological Survey Earth Sciences Report 2000-08, 67 p.

Fenton, M., Pawlowicz, J.G. 1997. Diamond indicator mineral anomaly from till sample site NAT95-134. Alberta Energy and Utilities Board, Alberta Geological Survey, Geo-Note 1997-1.

Fenton, M.M. and Pawlowicz, J.G., 2000. Quaternary Geology Northern Alberta: Information Sources and Implications for Diamond Exploration. Alberta Energy and Utilities Board, Alberta Geological Survey, GeoNote 2000-04.

Fenton. M.M., Schreiner, B.T., Nielsen, E. and Pawlowicz, J.G. 1994. Quaternary geology of the Western Plains. In: Geological Atlas of the Western Canada Sedimentary Basin. G.D. Mossop and I. Shetsen (comps.). Calgary, Canadian Society of Petroleum Geologists and Alberta Research Council, chpt. 26, p. 413-420.

Fulton, R.J. 1989. Foreward to the Quaternary Geology of Canada and Greenland. In Quaternary Geology of Canada and Greenland, R.J. Fulton (Editor). Geological Survey of Canada, Geology of Canada no. 1 (also Geological Society of America, The Geology of North America, v. K-1).

Fulton, R.J., compiler 1995. Surficial materials of Canada. Geological Survey of Canada, Map 1880A, scale $1 ; 5000000$.

Hamilton, W.N., Price, M.C. and Langenberg, C.W. 1999. Geological map of Alberta. Alberta Geological Survey,
Alberta Energy and Utilities Board, Map No. 236, scale $1: 1,000,000$.

Klassen, R.W. 1989. Quaternary geology of the southern Canadian Interior Plains. In Chapter 2 of Quaternary Geology of Canada and Greenland, R.J. Fulton (ed.); Geological Survey of Canada, Geology of Canada, no.1 (also Geological Society of America, The Geology of North America, v. K-1).

Pawlowicz, J.G. and Fenton, M.M. 1995a. Bedrock topography of Alberta. Alberta Energy and Utilities Board, Alberta Geological Survey, Map 226.

Pawlowicz, J.G. and Fenton, M.M. 1995b. Drift thickness of Alberta. Alberta Energy and Utilities Board, Alberta Geological Survey, Map 227.

Pawlowicz, J.G., Dufresne, M.B. and Fenton, M.M. 1998. Diamond Indicator Minerals from Auger Core Holes, A Possible Second Dispersal Train in the Peerless Lake Map Area (84B). Alberta Energy and Utilities Board, Alberta Geological Survey, Geo-Note 1998-2.

Paulen, R.C. 2002. Surficial Mapping 2002-2003. In: Rock Chips, Alberta Geological Survey Newsletter, Spring/Summer 2002, p. 9.

Paulen, R.C., Fenton, M.M., Pawlowicz, J.G., Weiss, J.A. and Campbell, J.E. 2002. Surficial geology of the Peerless Lake Area (NTS 84B). Program with abstracts, 2002 GAC/MAC, Saskatoon, v. 27, p. 89.

Pettapiece, W.W. 1986. Physiographic subdivisions of Alberta. Land Resource Research Centre, Research Branch, Agriculture Canada, Ottawa, scale 1:1500 000

Prest, V.K., Grant, D.R. and Rampton, V.N. 1968. Glacial Map of Canada. Geological Survey of Canada, Map 1253A, scale 1:5000 000 .

Prior G.J., Eccles D.R., Paulen R.C., Fenton M.M. and Pawlowicz J.G., 2003. Northern Alberta Quaternary Geology And Kimberlite-Indicator Mineral Surveys. 2003 Prospectors and Developers Convention, Indicator Mineral Methods in Mineral Exploration Short Course Notes.

Scott, J.S., 1976. Geology of Canadian Tills. In Legget, R.F. (ed.), Glacial Till, The Royal Society of Canada Special Publication No.12, p. 50-66.

Vincent, J.S., 1989. Quaternary Geology of the southeastern Canadian Shield. In Fulton, R.J. (ed.), Quaternary Geology of Canada and Greenland, Geological Survey of Canada, Geology of Canada No.1, p. 249-275.

Contact: M.M. Fenton, Alberta Energy and Utilities Board,

Alberta Geological Survey, $4^{\text {th }}$ Floor, Twin Atria Building,

$4999-98^{\text {th }}$ Avenue, Edmonton, AB, Canada

E-mail: mark.fenton@gov.ab.ca 
